\title{
Branduolio faktorius kappa B ir eozinofilai astmos patogenezèje
}

\author{
Ieva Janulaityte், Simona Lavinskienè \\ LSMU MA Pulmonologijos ir imunologijos klinika
}

Reikšminiai žodžiai: branduolio faktorius kappa B, NF-kB, eozinofilai, transkripcijos faktoriai, astma.

Santrauka. Astma yra kompleksinė uždegimo liga, kuriai būdingas kvėpavimo takų uždegimas bei remodeliavimasis ir bronchų reaktyvumas. Eozinofilai - tai kraujyje cirkuliuojantys granuliocitai, dalyvaujantys astmos patogenezeje. Eozinofily gyvavimas sergant alergine astma užsitęsia, kas gali sąlygoti kvėpavimo takų gleivinės pažeidimą ir remodeliavimąsi. Branduolio faktoriaus kappa B kelias buvo laikomas prototipiniu uždegimo signaliniu keliu, kurio pagrindas - uždegimo citokinų, chemokinų ir adhezijos molekulių genų raiška, reguliuojama NF-KB transkripcijos faktoriaus. NF-kB ilgai buvo laikomas „šventuoju graliu“ ar uždegimą slopinančių vaistų taikiniu, tačiau tyrimai parodè, kad lètinès uždegimo ligos yra itin kompleksiškas mechanizmas, įtraukiantis ląsteles ir jų baltymus. Šis transkripcijos faktorius atsakingas už daugelio uždegimo molekulių, tokių kaip citokinų, chemokinų bei adhezijos molekulių, gamybą ir jų genų raišką. NF-kB taip pat gali būti atsakingas už susilpnèjusią eozinofilų apoptozę.

\section{BRANDUOLIO FAKTORIUS KAPPA B (NF-KB) IR JO AKTYVACIJOS KELIAI}

Branduolio faktorius kappa B $(\mathrm{NF}-\mathrm{kB})$ - tai pirmasis atrastas ir aprašytas genų raišką imuninejje sistemoje reguliuojantis faktorius, dalyvaujantis igimtame ir igytame imuniniame atsake [1]. Šis transkripcijos faktorius dalyvauja ir organogenezeje, nelimfocitinèje bei limfocitinëje hemopoezèje, tiesioginiame antimikrobinio atsako mechanizmuose, uždegimo procesuose, $\mathrm{CD} 4+\mathrm{T}$ limfocitu diferenciacijoje ir inicijuojant bei reguliuojant imuninị atsaką. Visi NF-kB šeimos baltymai turi bendrą visiems Rel homologini domeną juc $\mathrm{N}$ terminaliniame gale. Šiai transkripcijos faktoriu šeimai priklauso RelA, RelB, c-Rel arba p50, p52. NF-kB pošeimio baltymai, ìskaitant RelA, RelB ir c-Rel, turi transaktyvacijos domeną savo $C$ terminaliniame gale. NF- $\kappa B$ yra svarbus ląstelinio atsako reguliatorius, kuris priklauso greitai reaguojančių pirminių transkripcijos faktorių kategorijai. Šie transkripcijos faktoriai yra neaktyvios formos, o ju suaktyvéjimas nepriklauso nuo baltymų sintezès ląstelèje. Tai leidžia NF- $\kappa B$ pirmam reaguoti $\mathfrak{i}$ žalingą ląstelès stimuliavimą, kaip antai: reaktyvias deguonies formas (RDF), tumoro nekrozès faktorių (TNF- $\alpha$ ), interleukiną 1- $\beta$ (IL-1 $\beta)$, bakterinius lipopolisacharidus (LPS), izoproterenoli, kokainą ir jonizuojančiąją spinduliuotę [2]. NF- B neaktyvūs dimerai yra nesujaudintose ląstelèse.

NF- $\mathrm{kB}$ yra izuoliuotas branduolio faktoriaus $\mathrm{k} B$ inhibitorių, kurių šeima vadinama $\kappa$ B inhibitoriais (І $\mathrm{KB}$ ). Šiu baltymų sekoje yra daug pasikartojančiu ankirino sekú. Būtent šios sekos apsaugo nuo NF-kB aktyvinimo [3]. ІкB šeimai priklauso IкB $\alpha$, ІкB $\beta$, IкB $\varepsilon$ ir Bcl-3. NFкB aktyvinimas sužadinamas per IкB baltymo degradaciją. Šioje reakcijoje dalyvauja IкB kinazé (IKK). IKK sudaryta iš IKKa ir IKK $\beta$ heterodimeriniu subvienetu ir pagrindinio reguliacinio baltymo, vadinimo NEMO (angl. NF- $K B$ essential modulator) arba IKK gama. Kai perduodamas signalas ị ląstelę, ІкB kinazè fosforilina dvi serino liekanas, esančias ant IKB reguliacinio domeno, tada vyksta IкB inhibitoriaus molekuliu modifikacija, vadinama ubikvintilinimu, dèl to proteosomos suardo šiuos baltymus.

I $B$ suirus, NF- $\kappa B$ kompleksas išsilaisvina ir patenka ił branduolį, kur ijungia tam tikrų genų raišką. NF- $k B$ sukelta genų raiška yra atsakinga už fiziologinị ląstelès atsaką ị dirginimą išskiriami citokinai, chemokinai, ląstele proliferuoja arba pailgèja jos gyvavimo laikas. Tuo pat metu vyksta raiška ir
IкB $\alpha$, kuris stabdo NF-kB veikimą, taip susidaro „kilpa“, kai iš neaktyvios formos paverstas i aktyvią NF- $\mathrm{kB}$ aktyvina savo paties inhibitoriaus raišką [4].

\section{NF-kB aktyvinimas}

Uždegimo atsakas - koordinuotas daugelio signalinių kelių suaktyvejjimas, kuris reguliuoja tiek uždegimą skatinančių, tiek slopinančiu citokinų raišką būdinguose audiniuose ir leukocituose. Daugiausia duomenu turima apie IL-1 ir TNF- $\alpha$ bei Toll-like mikrobinio atpažinimo receptorius, kurie priklauso IL-1 receptoriu šeimai. IL-1 ir TNF- $\alpha$ yra pagrindiniai uždegimo citokinai, kurie greitai išskiriami esant audinių pažeidimui ar infekcijai. TLR atpažista mikrobines molekules ir pateikia germinacines savęs neatpažinimo užkoduotas sistemas, kurios greitai atpažizsta uždegimo sukèlèją [5]. Tačiau yra duomenų, kad ne tik išoriniai, bet ir endogeniniai ligandai gali veikti TLR esant audiniu pažeidimui ir tam tikroms ligos stadijoms, kurios veikia kaip uždegimą skatinantys veiksniai, nors uždegimo nèra [6]. Nors yra struktūriškai skirtingi, šie receptoriai naudoja panašu signalų perdavimo mechanizmą, kuriame dalyvauja IKB kinazè (IKK) ir NF-kB aktyvacija [7]. Daugelyje ląstelių NF-кB kompleksas yra neaktyvus, nes citoplazmoje sudaro 


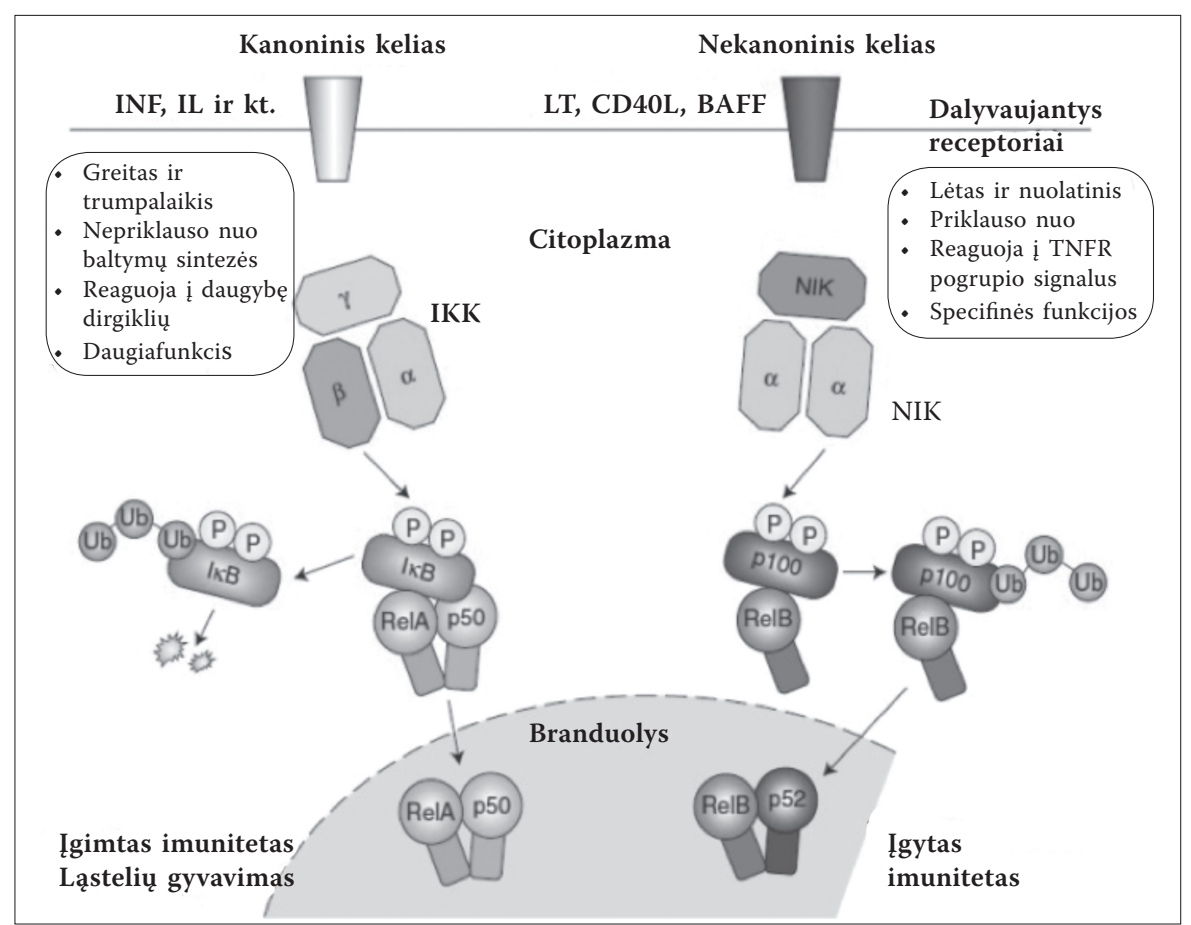

1 pav. Kanoninis ir nekanoninis NF-KB signalinis kelias [8]

kompleksus su inhibitoriais baltymais IкB. Skiriami du NF-kB aktyvacijos keliai: kanoninis ir nekanoninis (1 pav.).

Kanoninis NF- $\mathrm{kB}$ signalinis kelias suaktyveja, kai IkB baltymai yra suardomi IkB kinazių kompekso (IKK) $\beta$ ir $\alpha$ subvienetuc, NF-kB dimerai ieeina i branduolic [9] ir pradedama moduliuoti genu raiška. Manoma, kad kanoninis kelias yra svarbus alerginès astmos patogenezèje. Šj kelią aktyvina uždegimą slopinantys tarpininkai. Nekanoninis kelias suaktyvejja tarpininkaujant IKK- $\alpha$, kuris fosforilina $\mathrm{IkB}$, ir tuo metu proteosomos pradeda irti [10]. IKK komplekso $\alpha$ ir $\beta$ subvienetai yra katalitiniai, o reguliacinis, kitaip dar vadinamas NEMO subvienetu. Šis kelias reguliuoja limfinių organų vystymąsi bei B limfocitų aktyvumą.

Kanoninis NF-kB kelias pirmiausia buvo apibūdintas kaip atsakas ì TNF- $\alpha$ ir IL-1 signalus, prototipiškai šie uždegimo citokinai vaidina svarbų vaidmeni patogenezèje tokių lètinių ligu kaip reumatoidinis artritas, astma ir lètinė obstrukcinè plaučių liga (LOPL) [11-13]. NF-kB aktyvumas uždegimo metu yra susijęs su kanoninio kelio ir RelA- ar cRel sudarančių kompleksuc suaktyvejjimu. Atliktos studijos su reumatoidinio artrito pacientais atskleide, kad pažeistas audinys gamina daugiau nei iprastai uždegimo citokinų ir chemokinų, o ši reakcija yra priklausoma nuo NF- $\mathrm{kB}$ $[14,15]$. Panašūs ir žmogaus aterosklerozinio uždegimo bei uždegimo citoki- nų gamybos, taip pat priklausomos nuo NF-kB, studijų rezultatai [16]. Nustatyta koreliacija tarp NF-kB aktyvacijos ir uždegimo ligų tiriant gyvūnų artrito [17] ir alerginių kvèpavimo takų ligu modelius [18]. Tačiau ryši tarp NF-kB aktyvumo ir uždegimo ligų nèra lengva interpretuoti, nes išskiriami tiek uždegimą skatinantys, tiek slopinantys mediatoriai, todèl tikètina, kad ligos progresavimas priklauso nuo jų santykio [19].

Alternatyvus NF-кB aktyvinimo kelias - p100 fosfolinimas IKK- $\alpha$, dèl to suaktyvejja RelB/p52 heterodimerai. Tyrimai su gyvūnuc modeliais rodo, kad šis kelias svarbus organogenezei ir B limfocitų funkcionavimui [20, 21], tačiau jo reikšmè uždegimo ligu atveju nèra tiksliai žinoma [22, 23].

\section{EOZINOFILAI IR JŲ APOPTOZE் ASTMOS PATOGENEZE்JE}

Astma yra kompleksiné kvėpavimo takų uždegimo liga, kuriai būdinga kvėpavimo takų remodeliavimasis [24], bronchų hiperreaktyvumas [25, 26]. Eozinofilai yra vienos iš pagrindinių ląstelių, dalyvaujančių alerginès astmos patogenezèje ir uždegimo procesuose [27-30]. Eozinofilai - iš kaulų čiulpų ląstelių kilę kraujyje cirkuliuojantys granuliocitai, kurie sudaro $1-3$ proc. visų leukocitų [31]. Eozinofilai vystosi iš CD34+ pliuripotentinių progenitorinių ląstelių, kai jas stimuliuoja inter- leukinas 5 (IL-5), interleukinas 3 (IL-3) ir granuliocitu bei makrofagu kolonijas stimuliuojantis faktorius (GM-CSF) [32]. Šụ progenitorinių ląstelių paviršinè membrana turi daug IL-5 receptorių, todèl interleukino signalai lemia eozinofilų vystymąsi. Kita alerginiame uždegime dalyvaujanti ląstelè -2 tipo T limfocitai pagalbininkai (Th2) - išskiria IL-5, kuris veikia kaulų čiulpuose esančias CD34+ progenitorines ląsteles [33]. Plaučiuose eozinofilai atlieka daugeli funkcijų, kurios gali būti atsakingos už ligos eigą. Eozinofilai yra atsakingi už reaktyviưjuc deguonies formų (RDF) susidarymą ir išskiria toksines granules bei citokinus (IL-13, IL-5, TGF- $\beta$ ), chemokinus (CCL11, CCL22, matricos metaloproteinazes, granulių mediatorius ir kt.) [34, 35], be to, jie gali pateikti antigeną ląstelèms. Eozinofilai kraujyje išgyvena 5 val., o audiniuose - net iki 8-12 dienų.

Apoptoze - tai genetiškai užprogramuota ląstelès žūtis, kuriai prasidejjus ląstelejje suaktyvejja pačios ląstelès fermentai ir imamos skaldyti ląstelę sudarančios medžiagos [36]. Tai biologiškai svarbus procesas, reikalingas palaikyti audinių hemostazę, reguliuoti ląstelių augimą ir diferenciaciją. Vykstant apoptozei, negrižtamai suaktyvinama proteolizinių baltymų kaspazių (cisteino proteazių) kaskada (2 pav.). Suaktyvejjusios kaspazès proteoliziškai aktyvina kitas prokaspazes. Kai kurios kaspazès ardo struktūrinius ląstelès baltymus, pavyzdžiui, branduolio apvalkalo, citoskeleto bei tarpląstelinių jungčiu baltymus ir aktyvina endonukleazę, kuri suskaldo branduolio DNR. Svarbiausi apoptozès požymiai: DNR sutrūkinejja i fragmentus, branduolys susitraukia ir susiraukšlejja, pakinta pačios ląstelès forma. Eozinofilų apoptozę gali sukelti daugelis veiksnių: Fas ligazès, dauguma farmakologinių medžiagų ar TNF receptorių ligazès. $\mathrm{O}$ taip pat gali veikti vidinis kelias, susijęs su mitochondrijų veikla.

\section{NF KAPPA B VAIDMUO EOZINOFILŲ APOPTOZĖS METU}

Alerginès astmos metu NF- $\mathrm{kB}$ reguliuoja antiapoptozinị $\mathrm{Bcl}-2$ veikimą. Jei $\mathrm{Bcl}-2$ raiška padidejusi, eozinofilu gyvavimas pailgèja, susilpnèja ląsteliụ apoptozė kvėpavimo takuose. Eozinofiluc apoptozę gali sukelti daugelis veiksnių: Fas ar TNF receptorių ligazès, daugelis farmakologinių medžiagų. Kvėpavimo takų ląstelès pasižymi Fas ligando raiška, T limfocituose šio ligando raiška yra sumažejusi dèl Th2 
išskiriamų citokinų GM-CSF [37-39] ir IL-5 [36, 40]. Nustatyta, kad IL-5 yra eozinofilų koloniją stimuliuojantis faktorius [41]. Tyrimų su pelèmis modeliuose buvo nustatyta, kad Fas ligando neutralizavimas gali lemti kvépavimo takų eozinofiliją alerginès astmos metu.

Apoptozès reguliavimui itin svarbus onkogeno p53 baltymas, kuris kontroliuoja genų, valdančių ląstelès ciklą, DNR reparaciją, angiogenezę, baltymų degradaciją ir raišką. p53 baltymas gali sužadinti apoptozę per proapoptozinius $\mathrm{Bcl}-2$ šeimos narius ir slopinti antiapoptozinius Bcl-2 baltymus. Suaktyvejjus šiems procesams, ląstelès tampa itin atsparios daugeliui žūtị lemiančiu poveikių.

Alerginès astmos atveju intensyvụ uždegimą gali sąlygoti padidèjęs NF-кB aktyvumas, kuris slopina eozinofilų apoptozę. Be to, ilgesnį eozinofilu gyvavimą gali lemti ir GM-CSF bei IL-5. GM-CSF yra vienas pagrindiniuc citokinų, sąlygojančių ilgesnị eozinofilų gyvavimą kvėpavimo takuose sergant astma. IL-5 taip pat sąlygoja ilgesni eozinofilų gyvavimą, gali pakeisti antiapoptozinio Bcl-2 raišką eozinofiluose, reguliuoja kaspazes, vienus pagrindiniu apoptozès kaskadinio kelio elementų. Kad sustabdytu eozinofiluc apoptozę, IL-5 blokuoja kaspazių aktyvumą, apoptozè sutrikdoma ir eozinofilu gyvavimas pailgeja. Šie citokinai skatina ir eozinofilų migraciją bei jų kaupimąsi kvėpavimo takuose. Kai NF-kB slopinamas, eozinofilai reaguoja i TNF- $\alpha$ signalus, kurie ijungia apoptozès mechanizmą. NF-kB transkripciškai reguliuoja antiapoptozini $\mathrm{Bcl}-2$, apoptozès inhibitorius Mcl-1 ir c-IAP [37].

Jei signalinis kelias slopinamas, sutrinka šiu veiksniu reguliavimas ir skatinama eozinofilu apoptozè. Jei NF-кB aktyvinamas, suaktyvejja Bcl-2 raiška, pailgejja eozinofiluc gyvavimas ir sumažèja šių ląstelių apoptozė kvépavimo takuose. TNF- $\alpha$ yra slopinamas, kai NF-кB aktyvus ir nepažeisti jo signaliniai keliai $[42,43]$.

\section{APIBENDRINIMAS}

Eozinofilai - viena pagrindinių ląstelių, dalyvaujančiu alerginès astmos patogenezèje, o branduolio faktorius kappa B yra svarbus veiksnys, dalyvaujantis ne tik ląstelių vystymosi, bet ir diferenciacijos bei proliferacijos procesuose. Manoma, kad alerginès astmos atveju NF-kB aktyvacija sąlygoja lètesnę eozinofilų apoptozę, dèl to gali būti palaikomas intensyvesnis uždegimas kvèpavimo takuose.

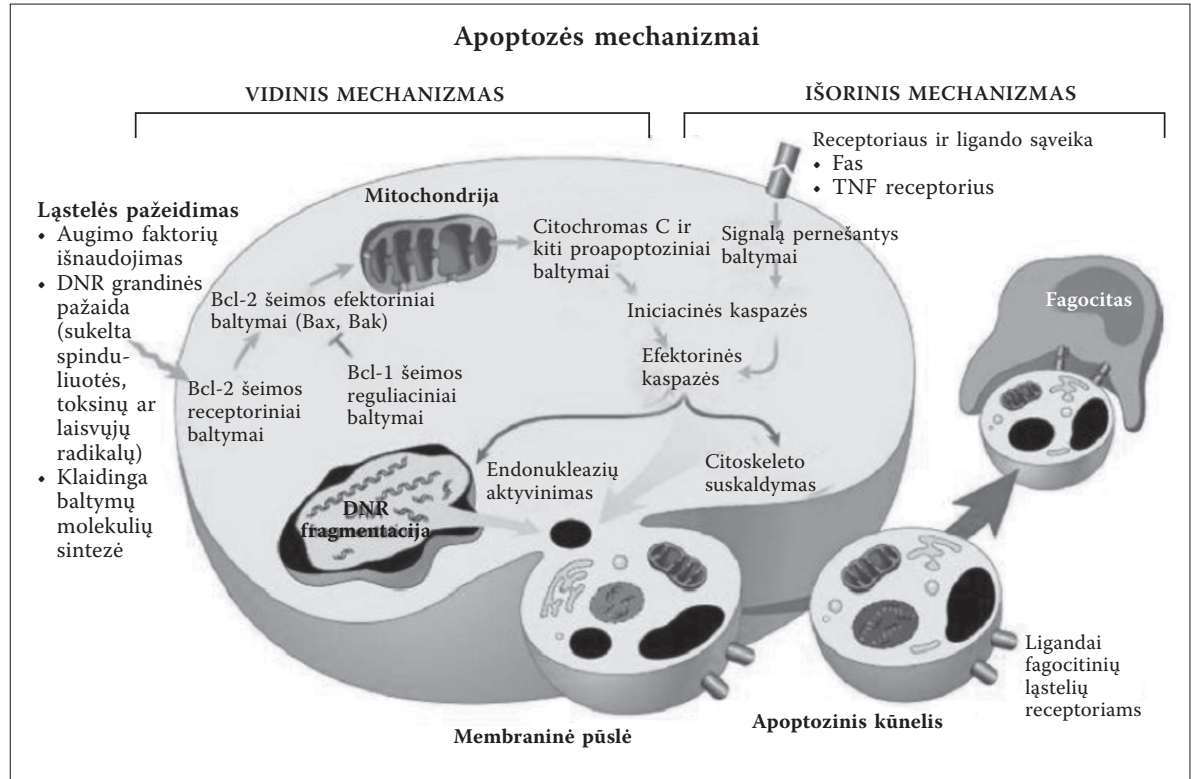

2 pav. Vidinis ir išorinis apoptozès mechanizmas

Išorinis signalinis kelias ijungiamas per signalines molekules, vadinamas ligandais, kurios prisijungia prie transmembraninių „mirties“ receptorių, aktyvinančių kitus transmembraninius receptorius, sudarydami ląstelès žūti sukeliantį signalini kompleksą. Šis kompleksas aktyvina kaspazę 8, kuri tiesiogiai gali aktyvinti kaspazę 3. Kaspazė 3 yra efektorinis baltymas, kuris sužadina ląstelès degradaciją. Aktyvi kaspazė 8 gali Bid baltymą suskaldyti i tBid, kuris svarbus vidiniam apoptozès signaliniam keliui. Vidinis signalinis kelias ijungiamas, kai ląstele patiria stresą. Kai gaunamas streso signalas, proapoptoziniai Bax, Bid ir Bak baltymai prisijungia prie išorinės mitochondrijos membranos. Jiems prisijungus, mitochondrija išskiria savo vidini turini ir citochromą $C$, dèl to citoplazmoje formuojasi kompleksai ir aktyvinama kaspazė 9, kuri toliau aktyvina efektorine kaspazę 3 . Tuo pat metu veikia ir Smac/Diablo baltymai, kurie slopina apoptozès inhibitorius [44].

\section{NUCLEAR FACTOR K B AND EOSINOPHILS IN ASTHMA PATHOGENESIS}

\section{IEVA JANULAITYTÉ, SIMONA LAVINSKIENÉ} DEPARTMENT OF PULMONOLOGY AND IMMUNOLOGY, MEDICAL ACADEMY, LITHUANIAN UNIVERSITY HEALTH SCIENCES

Keywords: nuclear factor kappa B, NF-kB, eosinophils, transcription factors, asthma.

Summary. Asthma is a complex immunologic and inflammatory disease characterised by the presence of airway inflammation, airway remodelling, and bronchial huperresponsiveness (BHR). Eosinophils are circulating granulocytes involved in pathogenesis of asthma. Multiple elements including interleukin (IL)-5, IL-13, chemoattractants are directly involved in recruiting eosinophils to the lung during allergic inflammation. Once recruited, eosinophils participate in the modulation of immune response, induction of airway hyperresponsiveness and remodeling, characteristic features of asthma. Airwy eosinophilia has been recognized as a predominant feature of allergic asthma and elevated numbers during the inflammation are often associated with the disease severity. Increased eosinophil survival and decreased apoptotic death are believed to participate in the asthmaticc airways. The nuclear factor NF-kB pathway has long been considered a prototypical proinflammatory signaling pathway, largely based on the role of NF-KB in the expression of proinflammatory genes including cytokines, chemokines, and adhesion molecules. The NF-KB pathway does indeed regulate proinflammatory cytokine production, leukocyte recruitment, or cell survival, which are important contributors to the inflammatory response. But, the antiapoptotic functions of NF-KB can both protect against inflammation, in the case of epithelial cell survival and mucosal barrier integrity, and also maintain the inflammatory response through persistent leukocyte activation.

\section{LITERATŪRA}

1. Yusuf D, Butland SL, Swanson MI, Bolotin E, Ticol $A$, Cheung WA, et al. The transcription factor encyclopedia. Genome biology. 2012;13(3):R24.

2. Chandel NS, Trzyna WC, McClintock DS, Schumacker PT. Role of oxidants in NF-kappa B activation and TNF-alpha gene transcription induced by hypoxia and endotoxin. Journal of immunology. 2000;165(2):1013-21.

3. Jacobs MD, Harrison SC. Structure of an IkappaBalpha/NF-kappaB complex. Cell. 1998;95(6):749-58.

4. Nelson $D E$, lhekwaba $A E$, Elliott $M$, Johnson JR, Gibney CA, Foreman BE, et al. Oscillations in NFkappaB signaling control the dynamics of gene expression. Science. 2004;306(5696):704-8.

5. Akira S, Uematsu S, Takeuchi O. Pathogen recognition and innate immunity. Cell. 2006;124(4):783-801.

6. Karin $\mathrm{M}$, Lawrence $\mathrm{T}$, Nizet $\mathrm{V}$. Innate immunity gone awry: linking microbial infection to chronic inflammation and cancer. Cell. 2006;124(4):823-35.

7. Ghosh S, Karin M. Missing pieces in the NFkappaB puzzle. Cell. 2002;109 Suppl:S81-96.

8. Lawrence T. The nuclear factor NF-kappaB pathway in inflammation. Cold Spring Harbor perspectives in biology. 2009:1(6):a001651.

9. Poynter ME. Airway epithelial regulation of allergic sensitization in asthma. Pulmonary pharmacology \& therapeutics. 2012;25(6):438-46.

10. Oh H, Ghosh S. NF-kappaB: roles and regulation in different CD4(+) T-cell subsets. Immunological reviews. 2013;252(1):41-51.

11. Holgate ST. Cytokine and anti-cytokine therapy for the treatment of asthma and allergic disease. Cytokine. 2004;28(4-5):152-7.

12. Chung KF. Cytokines as targets in chronic obstructive pulmonary disease. Current drug targets. 2006;7(6):675-81.

13. Williams RO, Paleolog E, Feldmann M. Cytokine inhibitors in rheumatoid arthritis and other autoimmune diseases. Current opinion in pharmacology. 2007;7(4):412-7.

Kiti literatūros šaltiniai (iš viso 44) redakcijoje. 